\title{
Challenges for university teacher education in Brazil posed by the Alpha Generation
}

Retos de la generación Alpha para la formación universitaria del profesorado en Brasil

Reptes de la generació Alpha per a la formació universitària de professors al Brasil

Rafael Nicolau Carvalho ${ }^{1, * \odot}$, Carlos Eduardo Ferreira Monteiro ${ }^{2 \odot}$, Maria Niedja Pereira Martins ${ }^{2}{ }^{(1)}$

1 | Federal University of Paraíba, Paraiba, Brasil

2 | Federal University of Pernambuco, Recife, Brasil

*Corresponding author: rafael.carvalho@academico.ufpb.br (Rafael Nicolau Carvalho)

Received: 07/29/2021 | Accepted: 11/24/2021 | Published: 01/15/2022

\begin{abstract}
Generation has been used as a theoretical construct for understanding the characteristics of age groups born in the same historical period. Children born since 2010 are considered to make up the Alpha Generation, whose members have had access to digital information and communication technologies from a very young age. In this article, we discuss the Alpha Generation in relation to initial teacher education. We have conducted an empirical study with 57 teaching-degree undergraduates from a federal public university in Brazil. Participants' responses indicate that they are aware of the challenges posed by the new generations and able to critically analyse the training processes in which they are engaged.
\end{abstract}

KEYWORDS: Alpha generation; University education; Digital technologies

Citation: Carvalho, R. N., Monteiro, C. E. F. \& Martins, M. N. P. (2022). Challenges for university teacher education in Brazil posed by the Alpha Generation. Research in Education and Learning Innovation Archives, 28,61-76. 10.7203/28.21408

Copyright: The Authors. Open Access: This article is distributed under the terms of the Creative Commons Attribution-NoDerivatives 4.0 International licence (CC BY-ND 4.0)

Funding: Research funded by CAPES from the Brazilian federal government
RESUMEN: La idea de generación se ha utilizado como un constructo teórico para comprender las características de los grupos de edad nacidos en el mismo período histórico. Actualmente, se considera que los niños nacidos a partir de 2010 forman la generación Alfa, que tiene acceso a las tecnologías de la información y la comunicación digitales desde temprana edad. En este artículo desarrollamos una discusión que aborda el tema de la generación Alfa para problematizar la formación inicial del profesorado. Se realizó un estudio empírico con 57 estudiantes de pregrado de la carrera docente de una universidad pública federal en Brasil. Las respuestas de los participantes indican que son conscientes de los desafíos de las nuevas generaciones y analizan críticamente los procesos formativos a los que acceden.

PALABRAS CLAVE: Generación Alpha; Educación universitaria; Tecnologías digitales

RESUM: La idea de generació s'ha utilitzat com un constructe teòric per a comprendre les característiques dels grups d'edat d'individus nascuts en el mateix període històric. Actualment, es considera que els xiquets nascuts a partir de l'any 2010 formen la generació alfa, els membres de la qual han tingut accés a les tecnologies de la informació i la comunicació digitals en una edat primerenca. Aquest article presenta una discussió sobre la generació alfa i el problema de la formació inicial dels professors. Una universitat pública federal de Brasil va fer un estudi empíric amb 57 estudiants de la carrera docent. Les respostes dels participants indicaren que eren conscients dels desafiaments de les noves generacions i analitzaren críticament els processos formatius a què accedien.

PARAULES CLAU: Generació Alpha; Educació universitària; tecnologies digitals 


\section{Practitioner Notes}

\section{What is currently known about the subject?}

- The literature discusses the concepts of generation as a theoretical construct that makes it possible to understand aspects of social and cultural dynamics

- The concept of Alpha generation addresses children and preadolescents living in a society permeated by actions intermediated by digital information and communication technologies.

- We live in a society with high technological development that implies considering changes to the ways of teaching and learning, the demands of the labour market and our sociability.

\section{What this paper adds?}

- This article focuses on the importance of understanding the concepts of the various generations and the Alpha generation associated with sociocultural and economic issues in people's context

- The article discusses the need to problematize the education of teachers who will teach the Alpha generation from an empirical study that considers the responses of undergraduate teaching degree students.

\section{Implications of this work for practice and future policy?}

- Teacher education courses need to consider contemporary challenges and aspects related to the discussion of Generation Alpha to rethink initial teacher education.

- Public policies for teacher education should consider the challenges of sociocultural and economic factors that the student population faces, but also implement teaching processes that enable future teachers to teach Generation Alpha.

\section{INTRODUCTION AND REVIEW OF THE LITERATURE}

The term generation has been used in several senses since the last decades of the 20th century (Feixa \& Leccardi, 2010). Generally, generation is associated with two distinct concepts: age group and a group of people born in the same historical period. The first concept understands that people change age groups as they get older, and thus, they will inevitably belong to different generations. In this sense, the perception that these people can incorporate social, cultural and symbolic elements is preserved, adapting to the aspects of the current time. In the second concept, generation is thought of as people who carry the marks of their historical period. Despite changing age groups throughout life, each person would belong to a single generation, and their place in the world would be defined from cultural, conceptual, worldview, behaviors and language aspects of a historical period, thus reflecting on the construction of a certain identity. The two meanings are important. The first is relevant to think about public policies for different population groups, for example, health actions, education and income distribution among the age groups of the population of a country. The second is useful for identifying behavioral changes, coexistence, intergenerational conflicts, ways of learning, work organization, and consumption of a generation (Gosseries, 2008; McCrindle \& Wolfinger, 2014).

On the other hand, both concepts have limitations regarding their universalist perspective, as they somehow ignore the complexity and diversity of people's psychosocial development processes at the same historical time. Since people of the same age or at similar stages of development can have a number of social and cultural experiences at the same historical moment, it can be somewhat limiting to attribute a homogeneous character to a generational group. However, in the scope of this work, we also emphasize the enhancing character of the generation concept to discuss a phenomenon of access to and use of digital information and communication technologies (DICT), which seems to be common to people of a same generation, even if we 
consider, for example, the economic inequalities and disadvantages of some groups in the same society. An example that can clarify this argument is that in Brazil, access to smartphones and, as a consequence, messaging apps, is very widespread (S. Oliveira, Carvalho, Monteiro, \& Carvalho, 2020). The use of those technological resources increased communication possibilities between children and young people, especially in the context of school closure in the Covid-19 pandemic, as those apps work as important pedagogical tools (Carvalho, Carvalho, \& Carvalho, 2021). However, this technological communication vehicle also allowed older users with less schooling and a critical sense to access disinformation frequently and quickly (François \& Monteiro, 2022)

Technological development is known to have produced significant advances hitherto unimaginable for humanity as advances in the forms of communication, interaction, work, production of goods and services, and education. Virtually all human, material, and immaterial production today is mediated by digital technologies. Thus, incorporating the technological development of society, particularly the DICT, to this idea of generation and its social, cultural, organizational impacts and its contribution to the historical marks (or characteristics) of each generation is an aspect to be considered.

Thus, after the Second World War, five generations are defined, considered the determining role of technological development. Although there is no consensus among the authors on the exact periods for each generation, we often find in the literature the following definitions: baby boomers (born between 1946 and 1964); generation X (born between 1965 and 1977); generation Y (born between 1978 and 1992); generation z (born between 1993 and 2009), and more recently the Generation Alpha (born as of 2010) (dos Reis, 2018; McCrindle \& Wolfinger, 2014; Ramadlani \& Wibisono, 2017; Tapscott, 2010). To understand the importance of the latter, it is necessary to explain the particular characteristics of those generations. In this definition, each generation carries specific traits that reflect their historical moment, leaving their mark on society. Obviously, those characteristics are not homogeneous, as they also reflect the sociocultural aspects of each context. Besides, technologies also printed new determinations.

The baby boomers received a kind of rigid and disciplinary education. However, they experienced significant social and cultural changes as they grew up, such as the popularization of TV and globalization. In turn, people of generation X, in many contexts, were censored by dictatorships and fought against these regimes and for more freedom. From a technological point of view, they witnessed the emergence of the first personal computers and the advent of the internet, thus experiencing a moment of technological transition. Generation Y, also known as milleniuns, for being immersed in a totally technological world with a strong connection to the internet and digital media, differs from the previous generation for living times of greater freedom, autonomy, and economic growth. Besides, people experienced changes in the family structure, such as women in the labour market and the reduction in the number of children, which led to new arrangements in which children's education became a priority (G. S. Oliveira, 2019; Tapscott, 2010; Viegas, 2015). Generation Z has a more intimate relationship with the media. People from this generation are considered digital natives because they had contact with such technologies from an early age. They experienced the popularization of mobile phones and their applications for various purposes, particularly instant communication, but also the consumption of new products such as games, as well as new forms of access to music, movies, videos, and news (dos Reis, 2018; Ramadlani \& Wibisono, 2017).This generation is also characterized by its ease to engage in digital social movements and create virtual communities. It is also considered the most tolerant and open generation and can easily express bodily and sexual freedom (Duffy et al., 2018). There are other implications in this portrayal of generations, such as the formation of identities, their ways of learning 
with repercussions on educational changes, and their role in the labour market.

In the specific case of Brazil, a good part of these characteristics described in the literature about each generation reflects, in a way, their experience with the impacts of globalization, counterculture movements and the advent of technology and digital media. However, the economic structure and diversity of sociocultural processes in Brazil imprints other particular characteristics, for example: the baby boomer generation in Brazil fought against the military dictatorship and participated in social movements for social rights and freedoms. Currently, members of this generation are close to retirement, but they continue to work and are engaged in social struggles and mark the history of their time. Generation X grew up in a time of political transition and uncertainties about the future, with the constant devaluation of the national currency, hyperinflation, but, at the very least, they experienced access to new information technologies. Generation $Y$ has already grown up in a political and social democratic context, with a globalized economy and the heyday of the economic plan of the Real (current Brazilian currency), and with wide access to the internet. This generation saw economic growth when Brazil became an economic promise along with the BRICs (Brazil, Russia, India, and China). Generation Z, in turn, is experiencing the great transformations of today, totally immersed in digital technologies, and has used them to defend agendas, freedoms, gender affirmation, sexual diversity, and the fight against racism, sexism and other prejudices (Viegas, 2015). These characteristics can be experienced differently, given the cultural and socioeconomic diversity of the Brazilian population, as well as the contemporary political context, marked by political polarization, neoconservatism and dismantling of public policies.

The term Generation Alpha was used by Australian sociologist McCrindle and Wolfinger (2014) to designate those born as of 2010. The term alpha is used because, being the first letter of the Greek alphabet, it marks the beginning of a new generational cycle. There is no consensus among researchers about how long this generation will last or when a new generation will emerge. Gen Alpha corresponds to the current children, who will soon become adolescents and young adults. This generation has had contact with various types of digital technologies that influence cognitive processes and identity construction from an early age. The development of Gen Alpha people is believed to be different from previous generations because it happens in a context of high technological evolution, which demands specific skills and characteristics, which will require changes in teaching, learning, consuming, working, and using technologies (dos Reis, 2018; McCrindle \& Wolfinger, 2014; Tootell, Freeman, \& Freeman, 2014). This generation may experience differentiations in the education system, which autonomy and customization of teaching may mark according to each student's competencies and skills and future projects.

As we can assume, the development of Generation Alpha heralds great challenges for education and particularly for teacher education, as it is believed to need an education connected with its time, compatible with the skills they developed from a very early age. There is still another variable to that assertion: educational contexts are formed by the interaction of different generations, which implies learning possibilities, where one generation can learn from the other in dialogical relations, but also by clashes and conflicts, especially regarding teaching approaches in which digital media are not yet considered.

Brazil has a large territorial area with a population of more than 213 million inhabitants. Most Brazilians undergo several structural problems, such as poverty, social inequality, and lack of access to basic living conditions for most of its population. Those problems pose major challenges for education, such as lack of adequate training for teachers, low quality of teaching processes, the precarious structure of schools and regional inequalities that impact the conduct of educational policies (Macêdo, Monteiro, \& Carvalho, 2020). In this formative environment -both in basic school and 
higher education- there are other aspects related to the coexistence between generations, for example, the unequal access and use of technological resources and how the different generations experience and incorporate them. Generation Alpha should be considered by educational policies, as data from the Brazilian Institute of Geography and Statistics (IBGE, 2010) indicate that $20.65 \%$ of the population consists of children and adolescents born as of 2010, which means over 20 million children. Most of them can be considered hyperconnected, which demonstrates the need for pedagogical approaches that meet their skills, i.e., an education connected with the technological development and the requirements of this society. We can say that in Brazil, the challenges of this generation are on the agenda of discussions for the construction of educational policies, which are under permanent review to connect with the needs of future generations in terms of quality of education, access to technologies and development of new teaching approaches. We can also infer that while seeking its place in the world, this generation will face new challenges, different from the previous generations, both in the local and global context, considering the signs and effects of various crises: climate, water, migration, and health (the more often emergency of pandemics).

To discuss this social context, one can resort to the concept of society in networks as "a social structure based on networks operated by information and communication technologies" (Castells, 2006, p. 20). In this assertion, the author points out that this society has promoted great changes in our communication and in our codes of life because it reproduces itself on a global scale and changes our social structure in the economy, labour market, science, technologies, communication, and education. Thus, in this society emerges a new profile of workers who need to be flexible to adapt to the changes in contemporary society. The construction of this profile will require converting the educational model into a learning process that teaches learning that requires new pedagogies, content, and learning processes (Castells, 2006).

Colis (2006) explains that the technological paradigm of the networked society points to a practical profile within this society: mobility of services, information, valuation of knowledge, capacity to work in teams and with interdisciplinary themes, need to work with digital technologies for information management, communication, creation, and learning. This profile points to three aspects that require a change in education: the mastery of technologies, knowledge management, and the development of creative capacity.

By recognizing the transformations in society and its technological development, international organizations have indicated the need to build new alternative models of education that include technologies in the teaching processes and that exploit collaboration and research. Those recommendations are in UNESCO documents (2009) and the National Common Curricular Base (BNCC), the normative document that defines an organic and progressive set of learning essential for basic school that all students must develop throughout their education. Among the general competencies of education, article 5 lists.

Understand, use and create digital information and communication technologies in a critical, meaningful, reflective, and ethical way in the various social practices (including school practices) to communicate, access, and disseminate information, produce knowledge, solve problems, and exercise protagonism and authorship in personal and collective life

(Ministério-da Educação2018, p. 9)

Some of those requirements that emerge from this new social organization relate to the characteristics described in the literature on Gen Z, but which are projected more intensely for future generations. 
In this sense, this article aims to analyze the formative experiences of teaching degree undergraduates at a Brazilian public university to teach future generations. Therefore, this study also seeks to characterize students from their generation, identify whether they feel prepared to work with the new generations, given the development of digital technologies and the characteristics attributed to Generation Alpha. And, in a way, verify whether digital information and communication technologies are part of their academic education.

\section{MATERIALS AND METHODS}

This research is exploratory for it seeks to deepen themes still underdeveloped by the construction of concepts, development of ideas, and proposition of more specific problems for future studies. Then, we want to develop an overview of the issue (Gil, 2008).

This is a qualitative study, as it aims to analyze the participants' academic formative experiences, particularising them in their subjective, cultural, and symbolic aspects, without seeking to generalize their results to a given population. Thus, we aim to illustrate the characteristics and experiences of the researched group to deepen the discussion on the investigated topic.

Thus, we chose teaching degree undergraduates from a public university in the Northeast of Brazil, which ranks among the 20 best universities in Brazil (E. Oliveira, 2021), to participate in the study. A teaching degree (licenciatura) is a full undergraduate degree that aims to qualify a teacher to work in basic education (UFPE, 2017). The education centre where the study was conducted was created in 1975 and currently offers pedagogical disciplines for 20 different undergraduate courses: Pedagogy, Physics, Chemistry, Mathematics, Biological Sciences, Physical Education, Music, Letters (Portuguese, French, Spanish, English, Libras), Performing Arts, Visual Arts, Graphic Expression, Dance, History, Geography, Philosophy, and Social Sciences. Each course is structured with its own curriculum, defined from national guidelines and based on a specific course pedagogical project. The teaching degree courses of that institution aim to:

train professionals, qualified in their specific areas, capable of: analyzing the complexity of educational phenomena and their articulations with the social, economic, political, and cultural reality; acting in different teaching and learning processes of the various areas of knowledge, interacting with teachers and professionals from other disciplines; acting critically and creatively in the educational system and in related contexts .

(UFPE, 2017, p. 31)

A questionnaire was applied through Google Forms. This data collection modality was chosen due to the suspension of face-to-face classes in Brazilian public universities since the emergence of the Covid-19 pandemic. Currently, students are in remote education, and thus, we gave priority to a virtual collection, respecting sanitary measures.

The questionnaire made available to students consisted of five parts. In part 1 , the participant had access to the Informed Consent Form, which explained the objectives of the study, its risks, and the participants' rights, as well as the right to anonymity, to have assistance in case of any damage, and to withdraw their participation at any time, in accordance with guidelines established by the National Council of Ethics in Scientific Research with Human Beings in Brazil. Only after this consent the other parts were made available. Part 2 consisted of items related to the characterization 
of the socioeconomic profile and education. The remaining parts combined open and closed items: questions about the participants' knowledge of the Alpha Generation (part 3); characterization of the participants' generation (part 4); questions about digital technologies and academic qualification (part 5).

The researchers met with the professors of the subjects taught by the Department of Psychology and Educational Guidance (DPOE) in the first half of 2021, to explain the objectives of the study so that the professors could socialize the collection instrument with the students. In that semester, ten classes participated in the investigation with an average of 300 students. It is noteworthy that those subjects are offered to students from 20 undergraduate courses who study pedagogical subjects at the education center (EC), hence the diversity of participants in different initial teacher education courses. Given the qualitative nature of the investigation and the universe studied, a convenience sample was chosen. As an inclusion criterion, students should be taking courses offered by DPOE professors in that semester.

We obtained a feedback from 57 respondents. The respondents were identified with the letter $\mathrm{P}$ (participant), followed by numbers that express the order of their reports, for example, P1, P2 and so on until the number 57.

From the systematization of the data and their subsequent analysis, we decided to organize the interpretation into three categories linked to the questions brought by the participants, namely:

1. Socioeconomic characterization of the participants

2. Generation Alpha and future perspectives

3. The training experiences, methodologies and the Generation Alpha

Each category gathered some questions that reflected the students' experience. During this process, the concepts of background and foreground (Skovsmose, 2014) were used to assist the analytical process. In the end, we assessed the findings and sought to make other theoretical inferences.

\section{ANALYSIS AND RESULTS}

In this section, we discuss the answers of the 57 participants who completed the semistructured questionnaire. Initially, we present some data of socioeconomic characterization of the participants who helped us to interpret their answers about Generation Alpha.

\subsection{Socioeconomic characterization of the participants}

Most participants (65\%) attend the Pedagogy teaching degree course, of which the great majority $(77.2 \%)$ are female, and $22.8 \%$ are male. These percentages corroborate a cultural stereotype in Brazil: the pedagogy course qualifies teachers for early childhood education and the initial years of elementary school, and, according to that pattern, young children's education should be in women's hands. The other 20 participants were from undergraduate teacher education courses which form teachers for work in the final years of elementary school and high school (geography 12.3\%; visual arts 5.3\%; biological sciences 3.5\%; history 3.5\%; mathematics 3.5\%; drama 3.5\%; social sciences $1.7 \%$; English 1.7\%). Only some of the courses are generally dominated by men, as is the case with the teaching degree in mathematics.

The youngest participant was 17 years old and the oldest was 59 years old. Most students were 17 to 26 years old in percentage terms (72\%). If we consider the mean age of all participants, we obtain the value of 25.7 years and the median of 23 years. 
A percentage of participants (8\%) are older than 42 years, indicating that a portion of participants may not have had access to higher education at an earlier age.

Presents the results on the participants' self-declaration in an ethnic-racial group. The online questionnaire allowed each participant to choose an alternative or declare another, according to the model Brazil adopts for self-declaration.

Table 1. Percentage distribution of participants by ethnic-racial group

\begin{tabular}{ll}
\hline Ethnic-racial group & Percentage \\
\hline White & 47.4 \\
Black & 28.1 \\
Indigenous person & 7.0 \\
Others / Pardo & 17.5 \\
Total & 100 \\
\hline
\end{tabular}

One of the options of the questionnaires was to choose the answer others. However, those who chose this alternative were asked to specify their self-declaration, and all wrote the term pardo (mixed), which is used in the national census (IBGE, 2010) to designate colour or race/ethnicity. This designation has been used since the 2000 Census, and all public policies adopt it to classify the population without pejorative purposes. In the Brazilian census system, the term colour does not necessarily refer to the colour of the person (one has the yellow colour, for example) but identifies the descent of certain ethnic groups. Thus, the term pardo is associated with people who descend from the miscegenation between different groups (Dias, Giovanetti, \& Santos, 2009). The black or pardo population is the majority in Brazil, representing $55.8 \%$ of the total population (IBGE, 2019).

Still commenting on the percentage distribution of Table 1 , we can identify that although the highest percentage of students self-declared as white, most students are distributed in the other self-declaration categories. Note that our respondents study in a university with a quota selection process, according to Decree No. 7.824 (2012), which benefits students who graduated from public schools, who come from families with an income equal to or less than 1.5 minimum wage per capita, people with disabilities, and indigenous, black, and pardo people.

The situation of the participants regarding the link with work activities indicates that although most participants did not work (54.4\%), a significant number of participants did (45.6\%).

Among the students who work, $26 \%$ said they work between 44 and 50 hours per week, $22.2 \%$ work 40 hours/week; $22.2 \%$ work 20 hours/week; and $18.5 \%$ work 30 hours/week. On the other hand, a lower percentage of participants $(11.1 \%)$ claimed to have a flexible workload, revealing that many students have long working hours (48.25). The respondents aim to qualify to have access to or improve their performance in the world of work, which seems favourable in a country with almost 11 million young people aged 15 to 29 years neither in the labour market nor studying or qualifying (IBGE, 2018), and with 14.8 million people -Brazil's unemployment rate today is $14.7 \%$ (IBGE, 2021).

The results obtained for this questionnaire about the participants' dwelling situation indicate that the vast majority of them live with family $(84.2 \%)$, and only a small percentage of the participants live on their own (15.8\%). These results were already expected since, in Brazil, young people and young adults predominantly live longer with their parents than young people in other countries and cultures. This situation has intensified not only for cultural but also for economic reasons, besides the access to a job that can guarantee housing support and payment. 
Table 2 presents data on the income of the participants' families. In general, the minimum wage is used as a unit to identify family incomes. Currently, the minimum wage in Brazil is BRL 1,100.00, which is equivalent to EUR 179.85 and USD 212.47, considering the respective exchange rates.

\begin{tabular}{ll} 
Table 2. Percentage distribution of participants who wor \\
\hline Student's family total incomes (Minimum wage) & Percentage \\
\hline Up to 1 & 18.9 \\
$>1-2$ & 32.1 \\
$>2-3$ & 28.3 \\
$>3-4$ & 13.2 \\
$>4$ & $7.5 \%$ \\
Total & $100 \%$ \\
\hline
\end{tabular}

We can identify that the family income of $18.9 \%$ of the participants is at most one minimum wage. In Brazil, social inequalities are very large, and among the most affected groups is the black and pardo population, which represents $75.2 \%$ of the population with the lowest incomes (IBGE, 2019).

The analysis of the information about the participants' profiles helped us understand better their realities and situate their opinions in an expanded sociocultural and economic context. Among the issues we analyzed, those highlighted demonstrate that when some characteristics and access to and use of technologies are taken into account, socioeconomic and ethnocultural inequalities impact a generation's specificities.

\subsection{Answers on Generation Alpha and horizons}

The first item of the questionnaire section addressing Generation Alpha asked participants what they knew about this generation. Most students had already heard about it (57.9\%), as we can see in the following testimonial examples:

It is a generation that has already been born within this perspective of a more technological, globalized world, which, despite liking to interact and connect with people, friends, use technology for this. They do not like to follow standards, however, they are more independent because they master all this technology, they are curious, they like to learn things through practice. They are not afraid to try the new, especially when they are not satisfied with the environments in which they live. They also accept in a more open way themes related to sexuality, politics, diversity, ideologies, etc. They are always thinking about what they think is best for them. (P5)

They are the so-called digital natives and the children of the generation known as millennials: children who are born immersed in digital technologies and media (P24)

It is composed of children born from 2010 onwards - also born in the digital age. Also, many experts anticipate that this group will be smarter and better creators of content, products and services than previous generations. (P28)

These testimonies point to characteristics that are commonly associated with the Alpha generation, such as its relationship with digital technologies. P5's testimony 
also suggests behavioral characteristics such as independence, curiosity, and more openness to discuss issues related to sexuality and politics.

Based on the characterizations of the generations commonly present in the literature and the ages reported in the questionnaire, we could identify that most participants (73.7\%) belong to generation $Z$ (born between 1993 and 2009). Subsequently, 19.3\% belong to generation $\mathrm{Y}$ (born between 1978 and 1992), and 5.3\% correspond to generation X (born between 1965 and 1977). The baby boomers (born between 1946 and 1964) represent only $1.8 \%$ of all students who answered the questionnaire. Even considering that a significant percentage of participants belong to generation $\mathrm{Z}$-which is supposedly more connected and skillful with digital technologies- and are more independent to learn and value their freedom of expression, we cannot generalize based only on literature classification, because in our experience as teachers, we realize that there is a diversity among students, considering their age and generation.

In some questionnaire items, we made available to the participants some characteristics of each generation, as presented in the literature, and asked if they identified themselves with those descriptions. Participants were warned that they should take the characteristics only as a parameter and not an exact description of their individual characteristics. Table 3 presents the percentage distributions of the answers for these items of the questionnaire.

Table 3. Percentage distribution of participants who work

\begin{tabular}{lllll}
\hline & $\begin{array}{l}\text { Identify } \\
\text { themselves }\end{array}$ & $\begin{array}{l}\text { Identify themselves in } \\
\text { part }\end{array}$ & $\begin{array}{l}\text { Do not identify } \\
\text { themselves }\end{array}$ & Total \\
\hline Baby Boomers & $10.6 \%$ & $47.3 \%$ & $42.1 \%$ & $100 \%$ \\
Generation X & $8.7 \%$ & $36.9 \%$ & $54.4 \%$ & $100 \%$ \\
Generation Y & $17.5 \%$ & $49.2 \%$ & $33.3 \%$ & $100 \%$ \\
Generation Z & $66.7 \%$ & $28.0 \%$ & $5.3 \%$ & $100 \%$ \\
Generation & $21.1 \%$ & $45.6 \%$ & $33.3 \%$ & $100 \%$ \\
Alpha & & & & \\
\hline
\end{tabular}

If we combine the percentages of the answers in Table 3 of the categories identify themselves and identify in part, we can see that $94.7 \%$ of the participants identify themselves with generation $\mathrm{Z}$, which could be expected because the characteristics associated with it correspond to most participants' generation. However, the respondents also seem to identify with elements that are not supposed to be part of their generation. Most participants identify themselves in some way with the baby boomers (57.9\%) and generations $Y(66.7 \%)$ and Alpha (66.7\%). The lowest percentage of identification among the generations described in the questionnaire referred to Gen X (45.6\%). We can infer that those results indicate that some aspects of the specific sociocultural context crystallize some values and characteristics, thus leading the individual to identify themselves, even partially, with different generations.

Those results make us consider that a specific generation will not be more technological than another. Instead, this characteristic depends on the very requirements of the social environment, the labour market, and the incorporation of technologies in normal life. Thus, we also consider that a supposedly "less technological" generation identifies with characteristics of the "more technological" generation but that they may lack opportunities to develop such skills during their lives.

In the next item, we asked students to pick from a list of characteristics the one with which they identified themselves. The characteristics most chosen by the participants and their respective frequency percentages were: solidarity $(86 \%)$; collaboration (82.5\%), creativity (82.5\%), flexibility $(75.4 \%)$, ease with technologies (75.4\%); autonomy (71.9\%), and dynamism (61.4\%). The least chosen characteristics were: stiffness (10.5\%) 
and conservatism (15.8\%). The characteristics suggest possible changes in teaching and learning that consider the characteristics the participants chose more frequently. Teaching has to be connected with social changes and with the people of that time, taking into account their previous skills and the development of new ones that will meet contemporary social demands.

Participants were also asked whether they believed that definitions of Gen Alpha corresponded to today's children. The analysis of their answers indicated that $84.2 \%$ said yes, and $15.8 \%$ said that the definitions partially referred to today's children. These data lead us to think that the characteristics that fall on Gen Alpha are recognized by most of the participants as a characteristic of this generation.

\subsection{Formative experiences, methodologies and Generation Alpha}

In the questionnaire, participants were also asked if their academic education is preparing them to deal with Generation Alpha. Most students answered that they were being partially prepared (56.1\%), a portion answered that they were prepared by the qualification $(26.3 \%)$, and a smaller number said that they were not (17.5\%). For example, some testimonials that express those opinions:

[in part] I believe that we have good methodological bases, then, it becomes a question of the teacher's adaptation and creativity. (P11)

No, because I speak for myself, in terms of digital mastery, we need a lot of training, besides, it is important to study a lot to understand the real needs of this new generation, taking into account the context in which they are inserted. (P7)

[yes] because we are also experiencing this generation due to several factors and mainly due to the pandemic, we had to forcefully adapt to this new generation because of the demands regarding work and remote education for the entire country. (P29)

The statements reflect that students value aspects of their education, such as the discussion of theoretical contents and the rigorous academic approach, but point out teachers' difficulties with using technologies and pedagogical methods. Participant P29 points out that in the pandemic context, there was an acceleration in the use of technological tools, which forced everyone to adapt.

Regarding the initial teacher education, we asked if the traditional teaching methodologies would still be effective in the courses to qualify future teachers. The answers indicated that $52.6 \%$ of the participants thought that those methodologies were partially effective, $38.6 \%$ indicated that they were not effective, and only $8.8 \%$ chose the answer that the traditional methodologies were effective. Some of the answers are presented below.

Traditional methodologies no longer serve the past generation very well, let alone Alpha and future ones. There should be revisions of methodologies to add to the technologies and information we have today. (P22)

A tuned generation, who uses technology all the time, neither accepts nor pays attention to a teaching that offers only the blackboard and the textbook as a source of teaching and learning. (P6)

I believe so, because although technology helps a lot, I do not believe it is the only source to provide quality education. (P19) 
Traditional methodologies do not provide spaces for students to deal with new technologies in the classroom. But I think the main problem is not the methodology itself, the problem is teacher education. The lack of knowledge, time to learn and train and know how to deal with new technological resources, such as games, equipment, etc., lead the teacher to repeat the same strategies used in several classes. (P11)

The participants recognize the historical importance of conventional methodologies, and some point out that the transition to new methods should happen gradually. A striking characteristic is the relationship they make between methods and the incorporation of digital technologies to understand and act with future generations, taking into account skills and the sociocultural context.

In another item, we ask about the elements the respondents think are primary to prepare them for the future and work with the new generations. They could choose alternative answers and could also write about other aspects that they considered important. The most frequent answers about the essential elements of education were: master digital technologies (87.7\%); understand contemporary social processes $(86 \%)$; know how to express oneself in the real and virtual world (86\%); know the different theories about the teaching and learning processes (82\%); skills of interpretation of figures, images, data, graphs, etc. (77\%), which suggest that participants find it essential to master digital technologies and recognize them as necessary skills. However, they also consider it relevant for their initial education to understand contemporary social processes, which requires articulating diverse know-hows and knowledge.

Another question was whether they felt any difficulty during their formation, which could be associated with a conflict of differences between generations. A significant number of students answered yes (42.1\%); a portion answered no (29.8\%), and another group said that in part (28.1\%). Participants were invited to justify their answers, as shown below:

Yes, when we are faced with teachers with a stance of knowledge holder, for example, when the student's opinion is not valued (P7)

We deal with this on a daily basis now when we went remote-learning. It is evident the unpreparedness and resistance to the use of technology not only of teachers but also of students and education workers of past generations ( $\mathrm{p} 19)$

The difficulty I felt was in relation to some teachers who use very outdated methodologies, forcing students to memorize instead of learning because we are often forced to go through highly stressful situations to carry out a poorly prepared assessment. (P33)

For the participants, intergenerational conflicts in the formative process result both from the difficulty in the use of technologies by teachers and students and from specific teachers' stances. From some participants' perspectives, some teachers are authoritarian and adopt a traditional teaching methodology. P45's testimony exemplifies this idea that may be the basis of intergenerational conflict in the formative process:

In remote teaching, my teachers had a lot of difficulty dealing with the technology, while some students had impeccable mastery. It made me reflect on how I need proper training to work with my students (P45)

However, some opinions demonstrate a relationship with other aspects that escape the idea of conflict only from the point of view of technologies, but rather from the social context: 
I believe that due to the different social contexts, there may be some conflict, but I must adapt to the new context in which I am inserted to reach those different generations (P37)

Teachers are having to reinvent themselves. After all, the traditional learning format is no longer as effective as before, and many educational institutions are already preparing 'the teachers of the future' to dialogue with the new classroom reality, acting as mediators and learning designers. (P29)

Participants also responded to an item about whether they believe that the current academic education model should be rethought and take into account technological development and new generations. The vast majority of participants answered yes, that the current model needs to be rethought (84.2\%); a small number said that there should be some change (14.4\%), and only one participant said that changes are not needed $(1.4 \%)$. For example:

I believe that training does not address current needs, neither do I think that we should modify our consolidated theoretical construction. However, some dose of it is required. (P14)

Yes, because we need to rethink the world, in a way, we need something that is constantly changing. (P8)

As generations evolve and change, qualifications and methodologies also need to accompany development, thus needing adjusting and reformulating concepts and methods of teaching and assessment. (P22)

In a way, the opinions highlight the need for changes in the sense of adequacy between methodologies and technological resources that are linked to a perspective that understands the social processes of change and the requirements that result from it. Those necessities go through the new skills and competencies required by today's society, which end up being incorporated into people's lives.

This time, it is not only the requirement of technologies as a substitute for faceto-face education, for example, but that those -technological, methodological and relational- changes are contemplated in the qualification, as well recalled by P23 in his account:

I believe that generation Alpha is being constituted by radically different childhoods from ours, in a world where changes will only be faster. I do not think that this requires the school to become virtual, that teachers be replaced by "avatars" or "machines" to learn, because education essentially requires human interaction and the beauty of being affected by the other. (P23)

Generally, participants see that the association of technologies with new teaching methodologies can improve learning by favouring a more participatory and interactive environment. And in this process, they also facilitate the forms of knowledge production and management. And in this perspective, participants bring important elements, such as teacher mediation, but with a new, more dialogic, collaborative profile and technological skills. They also indicate digital inclusion, greater access to the internet and technological resources, but critically and with a social view. 


\section{DISCUSSION AND CONCLUSIONS}

The discussion about Gen Alpha and its implications for prospective teachers' education, considering that they will work with this generation and with future generations, is relevant because it brings elements to assume a preeminent social problem, namely: how the rapid social transformations expressed by technological development change our forms of communication, work, relationships, leaving marks that are felt in the way we educate new generations.

From the analysis, it seems to us that there is an understanding of the definition and characteristics of the Alpha generation for most participants. They recognize those characteristics and are able to identify them in today's children, both with their use and ease with digital technologies and in more behavioral aspects. Therefore, they consider it important that these aspects are present in their education, as they recognize that their undergraduate courses do not prepare them enough to teach new generations.

Still on qualification, despite recognizing the importance of conventional methodologies, they suggest that changes are needed, such as new methods and especially with the adoption of the use of digital information and communication technologies. Students seem to understand the rapid changes that occur in society and understand that to critically accompany them, it is essential to master technological tools.

It also seemed to us that when experiencing intergenerational conflicts in their training, particularly in relation to teachers, the students fear suffering this type of conflict if they do not have adequate training to work with future generations. Perhaps, for this reason, they question some teachers' traditional methods and authoritarian stances. Thus, their opinions suggest the creation of a more interactive environment, mediated by technology, more human and also democratic, where there is no space for rigid postures and actions disconnected from their realities.

Most of the participants belong to Generation Z, but as observed, they share characteristics of other generations, which, as indicated, may be a characteristic of the Brazilian context. Our reflections also lead us to consider that the characteristics that are commonly associated with generations should not be fetishized, as there is a risk of turning them into allegories, driving the focus away from the central issue, in our view, the implications of technological development for the eduction of new teachers.

This time, participants with all their particularities -which include low socioeconomic power, coming from popular classes, residents of more impoverished regions and deemed behind time by the Brazilian elite- could participate, elaborate questions and reflections that challenge this fetishization. Obviously, the need to transform educational models and incorporate technologies is recognized, but without losing social contacts, values, and human presence in this process. Perhaps this recognition arose from the context of the Covid-19 pandemic we are going through. Technologies have favoured and are mediating the continuity of their qualifications, despite being against what some think and forcing students and teachers to adjust, develop new skills, and learn (Carius, 2021).

Thus, we can say that we all collaborate with our backgrounds (Skovsmose, 2014), both from the historical-cultural marks of our generation and the changes and learning that we promote throughout life. Generations are not static; they grow and change. And in this growth, there is a great possibility of building foregrounds, i.e., what we want for the future. This desire, in turn, signals for more open education, open to the different, more welcoming, more interactive and technological too. For them, who are living these experiences and for future generations.

The new generations easily incorporate technology and develop their skills, and it is their right to have appropriate training to expand and strengthen them. Thus, the technological repertoire should be incorporated into the school critically and creatively through more dialogic, interactive, participatory, and democratic methodologies. Only in this way, the future (hyper-connected, as they say) generations will 
develop a critical sense, autonomy, and flexibility that can be constituted as historical marks of their time.

\section{REFERENCES}

Carius, A. C. (2021). COVID-19 post pandemic, blended learning and artificial intelligence: is it the school virtualization? Research, Society and Development, 10(7), 1-11. https:// doi.org/10.33448/rsd-v10i7.16834

Carvalho, L.-M.-T.-L., Carvalho, C. F., \& Carvalho, R. N. (2021). Statistical data and COVID19 pandemic: reflections on statistical literacy dimensions. In C.-E.-F. Monteiro \& C.-F. Carvalho (Eds.), Temas emergentes em letramento estatístico (pp. 182-203). Pernambuco: Universitária UFPE. Retrieved from https://editora.ufpe.br/books/catalog/ book/666

Castells, M. (2006). A sociedade em rede: do Conhecimento à acção política. In M. Castells \& G. Cardoso (Eds.), A sociedade em rede: do Conhecimento à acção política (pp. 1730). Imprensa Nacional, Casa da Moeda. Retrieved from https://egov.ufsc.br/portal/ conteudo/sociedade-em-rede-do-conhecimento-\%C3\%A0-ac\%C3\%A7\%C3\%A3o-pol\% C3\%ADtica

Colis, B. (2006). E-learning e o transformar da educação na economia. In M. Castells \& G. Cardoso (Eds.), A sociedade em rede: do conhecimento à aç̧ão política (pp. 197204). Imprensa Nacional, Casa da Moeda. Retrieved from https://egov.ufsc.br/portal/ conteudo/sociedade-em-rede-do-conhecimento-\%C3\%A0-ac\%C3\%A7\%C3\%A3o-pol\% C3\%ADtica

Dias, J., Giovanetti, M. R., \& Santos, N. J. S. (2009). Como e para que perguntar a cor, raça/etnia no Sistema Único de Saúde? Sao Paulo: Centro de Referência e Treinamentos DST/Aids.

dos Reis, T. A. (2018). Study on The Alpha Generation and The Reflections of Its behavior in the Organizational Environment. Fournal of Research in Humanities and Social Science, 6(1), 9-19. Retrieved from http://www.questjournals.org/jrhss/papers/vol6-issue1/ C610919.pdf

Duffy, B., Shrimpton, H., Clemence, M., Thomas, F., Whyte-Smith, H., \& Abboud, T. (2018). Beyond Binary: The lives and choices of Generation Z. Report IPSOS Knowledge Center. Ipsos MORI. Retrieved from https://www.ipsos.com/sites/default/files/ct/publication/ documents/2018-07/ipsos-thinks-beyond-binary-lives-loves-generation-z.pdf

Feixa, C., \& Leccardi, C. (2010). O conceito de geração nas teorias de juventude. Revista Sociedade e Estado, 25(2), 185-204. https://doi.org/10.1590/S0102-69922010000200003

François, K., \& Monteiro, C. (2022). Reflections on Civic Statistics - A Triangulation of Citizen, State and Statistics: Past, Present and Future. In J. Ridgway (Ed.), Statistics for Empowerment and Social Engagement: teaching Civic Statistics to develop informed citizens. Springer.

Gil, A. C. (2008). Métodos e técnicas em Pesquisa Social. Sao Paulo: Atlas.

Gosseries, A. (2008). On future generations' future rights. The fournal of Political Philosophy, 16(4), 446-474. https://doi.org/10.1111/j.1467-9760.2008.00323.x

IBGE. (2010). Censo 2010. Author.

IBGE. (2018). No Brasil, cerca de 11 milhões de jovens não estudam e nem trabalham. Author.

IBGE. (2019). Desigualdades Sociais por Cor ou Raça no Brasil. Author. Retrieved from https:// biblioteca.ibge.gov.br/visualizacao/livros/liv101681_informativo.pdf

IBGE. (2021). Desemprego. Author.

Macêdo, M. C., Monteiro, C. E. F., \& Carvalho, R. N. (2020). Qualidades na Educação Matemática em cursos de Pedagogia: uma revisão sistemática da literatura. Revista Paranaense de Educação Matemática, 9(19), 647-664. Retrieved from http://revista .unespar.edu.br/index.php/rpem/article/view/693 
McCrindle, M., \& Wolfinger, E. (2014). The ABC of XYZ: understanding the global generations. UNSW Press.

Ministério-da Educação, a. (2018). BNCC (Base Nacional Comum Curricular). Educação é a base. Brasil: MEC.

Oliveira, E. (2021, 06 08). USP cai em ranking internacional de universidades, mas Brasil aumenta participação em lista. Retrieved from https://g1.globo.com/educacao/noticia/ 2021/06/08/usp-cai-em-ranking-internacional-de-universidades-mas-brasil-aumenta -participacao-em-lista.ghtml

Oliveira, G. S. (2019). Geração Alpha entre a realidade e o virtual: o sujeito digital. Bibliodigital. Retrieved from http://bibliodigital.unijui.edu.br:8080/xmlui/handle/ 123456789/5811

Oliveira, S., Carvalho, L., Monteiro, C., \& Carvalho, C. (2020). Teachers dialoguing about statistical literacy with support of messenger app for smartphones. Proceedings of the 16th International Conference Mobile Learning (pp. 129-132). Bulgaria. https://doi.org/ 10.33965/ml2020_202004R018

Ramadlani, A. K., \& Wibisono, M. (2017). Visual Literacy and character education for Alpha Generation. Proceedings International Seminar on Language, Education, and Culture ISoLEC (pp. 1-7). Indonésia. Retrieved from http://sastra.um.ac.id/wp-content/uploads/ 2017/11/01-07-Abdul-Khaliq-Ramadlani-Marko-Wibisono_LAYOUTED.pdf

Skovsmose, O. (2014). Foregrounds: Opaque stories about learning. Springer.

Tapscott, D. (2010). A hora da geração digital: como os jovens que cresceram usando a internet estão mudando tudo, das empresas ao governo. Agir Negócios.

Tootell, H., Freeman, M., \& Freeman, A. (2014). Generation Alpha at the intersection of technology, play and motivation. Proceedings of the International Conference on System Sciences, Estados Unidos da América (pp. 82-90). https://doi.org/10.1109/HICSS.2014.19

UFPE. (2017). Manual Acadêmico do Estudante. Pernambuco: Centro de Educação.

Viegas, R.-O.-M.-C. (2015). Geração Alpha: estudo de caso no Núcleo de Educação Infantil da UFRN. Repositório UFRN. Retrieved from https://repositorio.ufrn.br/handle/123456789/ 35093 